\title{
THE IMPACT OF DECENTRALISATION ON PUBLIC SECTOR CORRUPTION IN INDONESIA
}

\author{
Rizqi Bachtiar \\ Program Studi Ilmu Pemerintahan, FISIP Universitas Brawijaya Malang \\ Email: rizqibachtiar7@gmail.com
}

\begin{abstract}
Corruption is one of the illnesses of the government bodies that are still being combated in some countries, especially Indonesia. In order to reduce corruption cases, there are several reforms to be implemented, for example decentralisation. Decentralisation is expected to solve the problem since the policy narrows the gap between government and citizens. However, decentralisation does not eventually reduce corruption cases. Indonesia, for example, based on Corruption Perception Index has relatively stagnant ranking of combating corruption. Furthermore, there are few researches on the impact of decentralisation on corruption. Based on the explanation, this paper examines the drawbacks and benefits of the implementation of decentralisation on public sector corruption in Indonesia. Interestingly, this research finds that the implementation of decentralisation in Indonesia seems to have diverse impacts to eradicate corruption cases. For example, although Indonesia still has unsatisfied rank in combating corruption, the successfulness of KPK in arresting several local leaders indicates that decentralisation helps the enforcement institution in recognising the responsible actors on corruption acts. Therefore, this research is expected to fill the research gap on the impact of decentralisation on corruption in Indonesia.
\end{abstract}

Keyword: Decentralisation, Corruption, Indonesia.

\section{INTRODUCTION}

Corruption is one of the illnesses of the government bodies that are still being combated in some countries. In order to reduce corruption cases, there are several systems to be implemented, for example decentralisation. Decentralisation, based on UNDP (2004), is reconstituting the authority between central government and local government. McGuire (2010) cited in Asthana (2012, pp. 27-28) explains that decentralisation can reduce corruption since it narrows the gap between government and citizens. Furthermore, Faguet (2014, p. 2) emphasizes that decentralisation has been giving significant reform in improving the quality of governance. Those explanations reveal that decentralisation tends to be a good way to reduce corruption cases in every country around the world.

However, the implementation of decentralisation seems not successful enough to eradicate corruption cases in several countries, for instance Indonesia. Using decentralised system since 1999, Indonesia still has unsatisfied rank in combating corruption. According to Corruption Perception Index (CPI, 2018), in 2017 Indonesia ranks 96th out of 180 countries monitored in the world compared the ranking before implementing decentralisation that was 80th from 85 states in 1998 (CPI, 1998). Giving local governments more authority to manage their territory tends to give a chance to 
corrupt in several places in Indonesia. Komisi Pemberantasan Korupsi (KPK) or Corruption Eradication Commission in Indonesia (2014) reveals that more than 85 per cent of the leaders in local governments are indicated in corruption cases. This condition directly gives adverse impact for public services, the main objective of the government.

On the other hand, there are some positive impacts of the implementation of decentralisation in Indonesia. The successfulness of KPK in arresting several local leaders indicates that decentralisation helps the enforcement institution in recognising the responsible actors on corruption acts. Decentralisation also triggers public participation (Faguet, 2014, pp. 2-4). Nowadays, people can easily monitor the authorities' conducts since there has been some laws adopted requiring public entities to transparent their programmes. Hence, local leaders will have to think twice if they want to corrupt as it weakens their electability and public trust.

Therefore, this research examines the drawbacks and benefits of the implementation of decentralisation on public sector corruption in Indonesia. First, it addresses the adverse effects of decentralisation process, such as the spreading of corruption cases, the undelivered of public services, the lost of financial, and the circle of vicious. Second, it explains the positive impacts of decentralisation, such as encouraging public participation, making clear in identifying the responsibilities, and providing a chance for good figures in developing local regions.

\section{THEORETICAL FRAMEWORK}

In general, there are few researches that cover both sides on the impacts of decentralisation on public sector corruption in Indonesia. Many of those typically focus on the specific topic, either advantages or disadvantages of decentralisation in Indonesia. For example, Utami (2018, p. 35) argues that by having greater power and responsibility in decentralised era, some local officials in Indonesia seem not ready and capable to do their jobs by committing corruption. Any improper behaviour by officials reveals that the system of decentralisation in Indonesia needs to be improved. In line with Utami's explanation, Simanjuntak (2015, p. 111) believes that decentralisation in Indonesia is lost its essence. The condition, of course makes decentralisation in Indonesia vulnerable to be hijacked by free-riders and oligarchic politics.

Furthermore, the research conducted by Sujarwoto (2015, p. 1) finds that decentralisation in Indonesia is vulnerable to political dynasty. Comparing to previous centralised government, The political dynasty in decentralised era seems to be shifted from central government to local governments (Suaib and Zuada; 2015, p. 51). Therefore, lowering poverty rate as well as corruption cases in Indonesia's decentralisation era is likely to be challenging.

In summary, some researches on corruption in decentralised era in Indonesia seems to unpack the drawback sides. Yet, the advantages of the policy are rarely to explore and examine. Therefore in this research, examining both advantages and drawbacks is the best way to explore about corruption cases in decentralised era in Indonesia. Moreover, this research is also expected to fulfill the gap of the research by covering both sides. 


\section{METHODS}

This research utilises qualitative method in order to gain comprehensive data. The method also allows this research to have a wide range of data collection. Because of that, this research uses desk-based data collection..

\section{RESULTS AND DISCUSSION}

\section{Negative Impacts of Implementing Decentralisation \\ Spreading Corruption Cases}

Before the decentralisation era, corruption cases occurred in both executive and legislative due to the lack of checks and balances between those branches of authorities. This was happened because the majority of parliament was occupied by the same party, namely Golongan Karya (Golkar) (Suryadinata, 2007, pp. 33-35). Besides, the elected president, Soeharto, as the most powerful person in Indonesia had an enormous power in appointing his families, colleagues and relatives to lead some important public sectors. McLeod (2000, pp. 99-102) reveals that Soeharto had a prominent power to choose the leaders not only in central government, but also in local regions (provinces, kabupaten (districts), and villages). Therefore, the public services were only purposed to gain enormous advantages for certain groups of people.

However, after implementing decentralisation, the condition is almost the same, particularly in local level. Local leaders have a greater chance to abuse the power since based on the Law of The Republic Indonesia Number 23 Year 2014 on Local Government, article 65, they have an authority to plan and manage their own budget autonomously. One of the examples is a bribery case in Musi Banyuasin Regency in North Sumatera Province involving the Regent (Bupati) and the local parliament (Dewan Perwakilan Rakyat Daerah). According to the KPK (2015), the bribery conducted by the Regent was triggered by the intention to secure the approval of annual statement report and budget planning proposal by the local parliament. The local government seems unready to behave properly and the local parliament fails to execute its monitoring function. Unfortunately, this was not the only case. There are a number of swelling budget cases in Indonesia nowadays. Indonesia Corruption Watch, an NGO that focusing on corruption cases (2006), cited in Directorate General of Budget (2007) reveals that marking up of budget is the most common corruption case in the local governments. Some regulations tend to attract the marking up of the budget, for example Presidential Order Number 70 year 2012 on Procurement and Services. In some cases, the regulation allows the government to choose project winner from the government without the process of open tender. It attracts some officials to mark up the budget. Indonesia Procurement Watch (2007) cited in Directorate General of Budget (2007) explains that more than $80 \%$ of direct appointment of procurement is indicated in the practice of mark ups.

Next, according to the article 12 Law of The Republic Indonesia Number 23 Year 2014 on Local Government, the local government has an authority to manage the exploitation of natural resources. Several permits has been given to private entities without having any permission from the central government. In some parts of Sumatra and Kalimantan island, 
the local governments give an authorisation to cutting down the trees and use the forest as a palm oil field. This permit generates several problems, such as air pollution and deforestation. Edwards (2015) explains that remunerative relationship between leaders in local governments and owners of palm oil companies is the root of the problem. They have an illegal agreement in which palm oil companies have new plantation, and regent gets unofficial money. It contradicts with Article 33 Constitution of Indonesia that any resources is used to give benefit to the people. Based on principal-agent theory cited in Marquette and Peiffer (2015, p. 1), one of the problems in government is asymmetry information between government and people. Government that acts as an agent tends to know better than the principal that is acted by people. It gives a chance for government to cheat people by doing corruption.

Furthermore, some leaders in local governments tend to maintain his position by spreading their families or relatives to lead public services bodies or to be leaders of local governments in their region. Banten province is one of the examples that families of the governor have privilege to control the government. Before arrested by KPK in 2014 because of bribery case, the families of governor led some local governments and local public sector bodies. Based on $\mathrm{CNN}$ Indonesia (2015), brothers, sisters, brother inlaw, stepmother of the governor led some districts and municipalities in Banten and public sector body, such as Indonesian Chamber of Commerce and Industry (KADIN) branch Banten. The political dynasty in Banten fell down after the governor and her brother who led KADIN Banten arrested by
KPK because of involving in alleged bribes to the Constitutional Court Chairman (MK) in handling the dispute of election (Pilkada) in Lebak Regency, Banten. This case gives explanation that political dynasty gives more chances to do corruption as they control almost all the fundamental elements in local governments. Unfortunately, based on Law of The Republic Indonesia Number 1 Year 2015 on The Election of The Governors, The Regents and The Mayors, everyone who passes general requirements to become a governor or regent or mayor is allowed to be a candidate of a leader in local government, although their families also involves to be a candidate in other region elections. An incumbent is only allowed to declare as an election candidate once after the end of the tenure. However, some incumbents are trying to hold any power by pursuing as a vice regent or a leader in parliament after two periods lead. Another way is endorsing their families to be the next leader. Kompas, the national newspaper in Indonesia, (2013), reports that the wife of mayor in Malang, East Java, is one of candidates who participate in general election in Malang. This case gives explanation that there are some local leaders who reluctant to give their authority to other people.

\section{Undelivered Services}

Delivering public services is the main objective of the government. In Soeharto's regime, delivering public services in local governments were controlled by central government. Central government tended to focus on just developing Java Island. It impacted some separatist movements in some areas, such as Papua, the western part of 
Indonesia. Megantara (2013) reveals that the movement to separate from Indonesia was resulted by unfair development between Papua and Java Island.

By implementing decentralisation, based on Faguet (2014, pp. 10-11), it can improve public services since the regents know better about needs of local people than central government. However, in some cases, decentralisation makes services undelivered. Firstly, local leaders tend to focus on maintaining their authorities rather than delivering public services. Education is one of the clear examples that needs much more improvements in decentralisation system. Article 49 Law of The Republic Indonesia Number 20 Year 2003 on National Education System reveals that at least 20 per cent of both national budget and local governments budgets should be delivered to improve education system in Indonesia. In fact, based on Ministry of Home Affairs (2011), there are almost 15 per cent of educational infrastructures that is still under the standard. Furthermore, Daily Mail (2012) gives shocking news that some primary school students in Banten have to go to school by doing "Indiana Jones-style" to cross the river with the broken bridge. It seems unfair because the money that is allocated for education is not used properly. Antlov, Brinkerhoff, \& Rapp (2008, p. 2) maintains that governments tend to focus on their own interest rather than giving service to the people. Fiskal Indonesia (2014) reports that the budget for education is used for political purpose, such as general election.

Secondly, having authority to open general hiring by local governments increases the chances of illegal transactions between the selection committees and candidates. This is also influenced by the high rate of unemployment rate, more than 5 per cent by year 2014 (BPS, 2014). Antlov, et.al (2008, pp. 1-2) explains that the behavior of civil servants in Indonesia is still the same as Soeharto's regime. Anyone who wants to be a civil servant in local governments tends to have relationship or give money to the leaders of local governments rather than look at the qualifications. Thus, it makes a chance of abuse of power, where the agent (civil servant) tends to obey the principal (leader in local government) rather than delivering services to the people.

\section{Financial Loss}

According to Transparency International (2004), Indonesia lost at least US \$35 billion when Soeharto led Indonesia over 32 years. It makes him one of most corrupt leaders in the world. The most income came from several foundations that were given donations by government from national budget and some enterprises. Decentralisation is emphasised to solve that problem because it can improve public accountability and reduce corruption (Faguet, 2014, p. 5). It is seemed logic as in New Order era local leaders tended to obey the president that had elected them to be leaders rather than civil society. Nowadays, because of local leaders elected by people, candidate of local leaders have to listen what people want and convince the people that they will deliver services as good as possible.

However, after implementing decentralisation, Indonesia, based on Indonesia Corruption Watch (2012) cited in Kompas (2012), lose at least US \$3 billion in just 7 years. It indicates that decentralisation is not merely eradicating corruption cases. 
Furthermore, the high cost of local governments' elections attracts some leaders to corrupt in order to gain more money. Poltracking Indonesia (2014), an NGO that focusing on politics, reveals that a candidate of governor needs approximately US $\$ 11,14$ million for financing the campaign. It is much more higher than the salary of a governor that is just around US $\$ 670$ per month. The cost for campaign is not only from the candidates, but also from political parties that endorse them. It explains that after the candidates being elected, they tend to gain unofficial money as much as possible to balance their money. In one hand, general election in local government implements democracy aspect. On the other hand, the implementation of general election also opens a chance to corrupt. Moreover, the high cost of election makes political parties endorsing the candidate who has strong financial power. Antlov, et.al $(2008$, p. 2) maintain that one of political parties purposes to recruit political leaders is fundraising. It seems that financial power is important rather than looking at the quality of the candidate. Consequently, it appears some problems, such as corruption as mentioned above and incompetency to lead local government.

\section{Vicious Circle}

When Soeharto led Indonesia from 1968 to 1998, his political party, Golkar, always won in every general election. Every policy that was made had to give some advantages to Golkar. Suryadinata (2007, pp. 33-35) explains that all civil servants had to be loyal to Golkar, if they wanted to be secure, especially their positions. Almost all of public sectors in Indonesia were controlled by Soeharto and his party. This condition was continuously happened during the New Order regime. Marquette and Peiffer (2015, p. 1) maintain that this kind of behavior is influenced and exampled by others. Thus, this vicious circle was difficult to be eradicated in Soeharto's era.

In decentralisation era, the condition of eradication corruption is almost the same. First, anyone who wants to be a leader in local governments should join and be endorsed by political party, although law in Indonesia gives a chance for independent. Article $1 \mathrm{Law}$ of The Republic Indonesia Number 1 Year 2015 on The Election of The Governor, Regent, and Mayor to Become Law maintains that individuals have a chance to register as candidate of local leader in general election. However, Article 41 Law of The Republic Indonesia Number 8 Year 2015 on Changes to The Law Number 1 Year 2015 Concerning The Establishment of Government Regulation in Lieu of Law Number 1 Year 2014 on The Election of The Governor, Regent, and Mayor to Become Law tends to reduce participation of the individuals because they have to have at least $7,5 \%$ support from total voters as prerequisite to register. It gives more chances for candidate endorsed by political party to win the general election. Political parties take an important part in general elections, although some people tend to be sceptic as a result of some corruption done by members of political parties (Indonesia Corruption Watch, 2013; Transparency International Indonesia; 2013). This condition attracts some corruption cases and is continuously happened as general election is periodically held.

Second, general election tends to give a chance for candidate of local leader who has financial power. Indonesia Corruption Watch 
(2010) reports that candidate who has strong financial power does not ensure to have the best competence. Banten case reveals that political dynasty is difficult to eradicate as theirs financial support are powerful. It also reveals that most local leaders have a background as a businessman or are endorsed by businessman. Unfortunately, this financial power seems likely to be used to give voters instant benefit, such as money politics. The cost of money politics will return, however, by doing corruption after elected. This kind of vicious circle seems difficult to stop because there is no strict regulation to prevent money politics in some ways.

\section{Positive Impacts of Decentralisation Public Participation}

Giving citizens authority to monitor the government was not the priority in Soeharto regime (Lubis, 2007, p. 73). It caused several local leaders that were involved in corruption cases had less attention in Soeharto era. Civil society tended to be positioned as an agent rather than a principal. However, after implementing decentralisation, civil society has greater authority to monitor the government than before.

Firstly, Law of The Republic Indonesia Number 14 Year 2008 on Public Disclosure gives an opportunity to citizens to participate in every single policy that is made by local government. Every public service body has to release annual report to the people, and the citizens are allowed to collect any information related to the bodies. It reduces local governments to abuse their authority because all of their activities have to be reported to citizens annually. If there is any conduct related to abuse of power by administrators, people can report it to KPK. Furthermore, in this globalized era, there are many cuttingedge of technologies that can monitor public service bodies, such as social media, television and world-wide-web. Bandung City is the example that the local government implement media social as a way to be more closely to the citizens. People can access and comment about the condition of their city that is freely seen by other people around the world. However, if there is any corruption case, it spreads quickly by social media that can reduce public trust. Thus, it stimulates local government to deliver services as good as possible in order to improve public trust.

Secondly, Law of The Republic Indonesia Number 23 Year 2014 on Local Government gives people a chance to vote the best candidate of local government leader in general election. If the campaigned programmes are not implemented, it will reduce their electability to lead in the next period. The successfulness of Joko Widodo, the President of Republic Indonesia, when he was as a Mayor in Solo can justify that explanation. Metrotvnews, a national mass media in Indonesia, (2014) reports that Joko Widodo led Solo in the first period after just gaining 36,62 percent voters. He then proved to the citizens by actively campaigning anticorruption movement and improving public sector services. Interestingly, it delivered him to win general election for the next period by gaining more than 90 percent voters. It reveals that convincing citizens by enhancing public services can increase public trust to the government (Hartley et.al, 2008, pp. 3-7).

Making Clear The Responsibilities of The Government's Action 
As already mentioned that centralised government in New Order era makes corruption cases difficult to detect, when there were any corruption cases, it was difficult to find either who was included in the case or who would be brave enough to open the case. All of civil servants, local government leaders and municipalities ought to obedient the central government. Rule of law that had to be the guardian of justice was weak (McLeod, 2000, p. 102).

\section{Implementing decentralisation,} however, gives two opportunities to combat corruption. First, KPK as anti-corruption body can localise corruption cases in particular local government. As usual, corruption cases involve either leaders in local governments or municipalities. If there is any corruption case indicated in local government, KPK just unpacks the case by focusing on these two bodies. It eases in the process of law enforcement in local government. Second, decentralisation makes citizens know who has the responsibility in particular project. Faguet (2014, pp. 5-6) reveals that decentralisation makes it clear to know who deliver the public goods and services and who use them. It makes less difficult for officers who want to gain unofficial money as people monitors all of their activities in the public services bodies. The information about local leaders that are arrested by KPK for more than 80 percent above also maintains that there is no secret room in public services bodies. It is supported by many mass media that report the government activities actually. Every corruption case that is local leader involved tends to reduce the electability of either the leaders or political party that endorse them
(Faguet, 2014, pp. 5-7). It impacts especially on the next general election.

\section{A Future to a Good Local Leader}

As mentioned above that New Order era made people having no choice to elect a leader in local government, bribery cases often occurred in this area in order to secure the candidate's position to be appointed by president.

In this decentralisation era, a stellar leader has an opportunity to lead the local region better. For instance in the City of Bandung, the Province of West Java, the present Mayor can manage the city greatefully (British Council, 2014). As an urban designer and architect, Ridwan Kamil designs Bandung as a vibrant and dynamic urban city. With the slogan of Bandung Juara (Bandung is the winner), he enhances public sector services by some policies, for example introducing social media as the way for society to criticise, complain, and communicate to the Bandung government. People can directly inform to the Mayor the misconduct of bureaucracy or the case of corruption. In one hand, this programme is good in reducing the gap between the authorities and the principals. On the other hand, the civil servants are triggered to improve their performance because everyone is keeping an eye on them.

Beside increasing the performance of the staffs, Ridwan Kamil also try to enhance the quality of open space public infrastructure by creating theme parks under the flyoverroad and rehabilitating the recreational function of open space public areas as a means of gathering and leisure. Because all of his achievements, Ridwan Kamil was nominated 
as one of best mayors in the world (The City Mayors Foundation, 2014).

Not only Ridwan Kamil, Tri Rismaharini, the Mayor of the City of Surabaya in the Province of East Java was also nominated as the third best mayor in the world in 2014 by The City Mayors Foundation (2014). After being elected, she reforms some public services, for example implementing electronic procurement in preventing corruption (LPSE, 2015). Electronic procurement is used to minimise a contact between the authority and the client or operator in order to avoid illegal transaction and any forms of bribery. It also encourages fair trade mechanism for any companies who want to join the project. People can also see the process of the tender and give their opinions about the tender. This transparent action hinders the civil servants to receive a bribery and persuade the result of tender in inappropriate manners. Therefore, decentralisation gives more space for capable people to lead their regions.

\section{CONCLUSION}

Indonesia has struggled to combat corruption cases in public sector services for more than three decades. In order to reduce this abuse of power, decentralisation is implemented. However, the implementation of decentralisation in Indonesia seems to have two consequences. In one side, it gives more chance to local authorities to abuse their power that causes some adverse impacts, for instance ineffective public services, vicious circle and financial loss. On the other side, decentralisation also has positive impacts in creating a better governance system, especially in encouraging public participation, giving a clear direction to analyse the responsible actors, and providing an opportunity to some competent people to lead in local level.

On the other hand, decentralisation in Indonesia needs a careful approach in order to minimise a chance to corrupt. Hofman and Kaiser (2002) with their argument about the "Big Bang" impact of decentralisation in Indonesia reveal that Indonesia has to consider the balance of between maintaining unitary state and giving some authorities to local governments. Any opportunity that is given to local government ought to improve public service in Indonesia and not overlap with central government. It needs political will from both executive and parliament in Indonesia to make a strict regulation in reducing some adverse impact of the implementation of decentralisation. However, the content of the strict regulation needs to be defined by some researches. Thus, research on decentralisation in Indonesia, in the future, takes an important part in improving decentralisation system in Indonesia.

\section{REFERENCE}

Ainun, Y. (2013) Maju Jadi Calon Wali Kota, Istri Peni Siap Dipecat. Kompas. Retrieved from http://nasional.kompas.com/read/20 13/02/25/1402066/Maju.Jadi.Calon. Wali.Kota.Istri.Peni.Siap.Dipecat

Antlov, H., Brinkerhoff, D. W., \& Rapp, E. (2008). Civil Society Organizations and Democratic Reform: Progress, Capacities, and Challenges in Indonesia [online]. In RTI International, Paper presented at the 
37th Annual Conference, Association for Research on Nonprofit Organizations and Voluntary Action, Philadelphia 20-22 November. Retrieved from https://scholar.google.co.uk/scholar? $\mathrm{q}=$ civil+society+organizations+antlov $\& b \operatorname{tnG}=\& h l=e n \& a s \_s d t=0 \% 2 C 5$

Asthana, A.N. (2012). Decentralisation and Corruption Revisited: Evidence from A Natural Experiment. Public Administration and Development, 32/1, 27-37.

BPS (2014) Unemployment Rate (UR) by Province, 2002-2014. Badan Pusat Statistik Indonesia. Retrieved from http://www.bps.go.id/linkTabelStati s/view/id/981

British Council (2014) Ridwan Kamil. Retrieved from http://creativeconomy.britishcouncil. org/people/ridwan-kamil/

CPI (1998) Corruption Perceptions Index 1998. Retrieved from http://www.transparency.org/resear ch/cpi/cpi_1998

CPI (2018) Corruption Perceptions Index 2017. Retrieved from https://www.transparency.org/news / feature/corruption_perceptions_ind ex_2017?gclid=Cj0KCQjwpvzZBRCbA RIsACe8vyJ9shxqJuXSWp1zyCbt6tfC b3mX0TQZuDg3z_f3_wC6uD56LcH1 XOQaAuTAEALw_wcB

Directorate General of Budget (2007) Penggelembungan Anggaran Modus Laten Korupsi. Retrieved from Available at <http://www.anggaran.depkeu.go.id / web-print-list.asp?ContentId=88>
Edwards, S. (2015) Why Indonesia Can't Stamp Out Fires That Have Cast A Haze Over South-East Asia. The Conversation. Retrieved from https:// theconversation.com/whyindonesia-cant-stamp-out-fires-thathave-cast-a-haze-over-south-east-asia50029

Faguet, J. P. (2014). Decentralization and Governance. World Development, 53, 2-13.

Fiskal Indonesia (2014) ICW: Anggaran Pendidikan Banten Jadi Lahan Basah Korupsi Berjamaah. Retrieved from http:/ / www.fiskal.co.id/berita/fiskal -12/1354/icw:-anggaran-pendidikanbanten-jadi-lahan-basah-korupsiberjamaah\#.Vnv8FISwzdt

Hari W., L. (ed.) (2012, 05 December) Koruptor Rampok Rp 39,3 Triliun. Kompas. Retrieved from http:/ / nasional.kompas.com/read/20 12/12/05/06154374/Koruptor.Rampo k.Rp.39.3.Triliun

Hartley, J., Donaldson, C., Skelcher, C. \& Wallace, M. (eds.) (2008) Managing to Improve Public Services. 1st ed. United Kingdom: Cambridge University Press

Indonesia Corruption Watch (2013) Survei TII soal Pandangan Masyarakat; Partai Politik dan DPR Lembaga Terkorup. Retrieved from http://www.antikorupsi.org/en/cont ent/survei-tii-soal-pandanganmasyarakat-partai-politik-dan-dprlembaga-terkorup

Kisiel, R. (2012, 20 January) Think The School Run is Bad? Children Face Indiana Jones-Style River Crossing Every Day 
After Floods Cut Off Their Community. Daily Mail. Retrieved from

http:/ / www.dailymail.co.uk/news/a rticle-2088998/Think-school-run-bad-

Children-face-Indiana-Jones-styleriver-crossing-EVERY-day-floods-cutcommunity.html

KPK (2014) Corruption Majority Occurred in

The District. Retrieved fromhttp:/ / www.kpk.go.id/id/berita / berita-sub/2386-mayoritas-korupsiterjadi-di-kabupaten>

KPK (2015) KPK Set 4 Suspected Bribery Again Regency Muba. Retrieved from http:/ / kpk.go.id/id/berita/ siaranpers/2895-kpk-tetapkan-lagi-4tersangka-suap-dprd-kabupatenmuba

Law of The Republic Indonesia Number 20

Year 2003 on National Education System

Law of The Republic Indonesia Number 14 Year 2008 on Public Disclosure

Law of The Republic Indonesia Number 23

Year 2014 on Local Government

Law of The Republic Indonesia Number 1

Year 2015 on The Election of The

Governors, The Regents and The Mayors

Law of The Republic Indonesia Number 8

Year 2015 on Changes to The Law Number 1 Year 2015 Concerning The Establishment of Government Regulation in Lieu of Law Number 1 Year 2014 on The Election of The Governor, Regent, and Mayor to Become Law

LPSE (2014) E-Procurement. Pemerintah Kota Surabaya. Retrieved from https://lpse.surabaya.go.id/eproc/ap $\mathrm{p}$

Lubis, S. (2007) Partisipasi Masyarakat dalam Kebijakan Publik. Jurnal Demokrasi. 6(1), pp. 73-78

Marquette, H. \& Peiffer, C. (2015) Corruption and Collective Action Developmental Leadership Program, University of Birmingham

McLeod, R.H. (2000) Soeharto's Indonesia: A Better Class of Corruption. Agenda 7/2, 99-112

Megantara, S. (2013) Upaya Organisasi Papua Merdeka (OPM) Dalam Menggalang Dukungan Internasional Untuk Kemerdekaan Papua. Retrieved from http:/ / repository.upnyk.ac.id/7127/

Ministry of Home Affairs (2011) Pemerintah Perbaiki Sekolah Rusak. Retrieved from

http://www.kemendagri.go.id/news /2011/08/24/pemerintah-perbaikisekolah-rusak

Poltracking Indonesia (2014) Corruption and The High-Cost District Head Elections. Retrieved from http:/ / www.poltracking.com/artikelhanta-yuda/359-corruption-and-thehigh-cost-district-head-elections

Simanjuntak, K. M. (2015). Implementasi Kebijakan Desentralisasi Pemerintahan di Indonesia. Jurnal Bina Praja: Journal of Home Affairs Governance, 7(2), 111-130.

Stefanie, Christie \& Kusumadewi, Anggi (2015, 09 July) Riwayat Tanah Banten di Bawah Kaki Dinasti Atut. CNN Indonesia. Retrieved from http:/ / www.cnnindonesia.com/ politi k/20150709101059-32-65363/riwayat- 
tanah-banten-di-bawah-kaki-dinastiatut/

Suaib, E. (2016). Fenomena 'Bosisme Lokal'di

Era Desentralisasi: Studi Hegemoni Politik Nur Alam Di Sulawesi Tenggara. Jurnal Penelitian Politik, 12(2), 51-69.

Sujarwoto, S. (2016). Desentralisasi, dinasti politik dan kemiskinan di Indonesia. Jurnal Ilmiah Administrasi Publik, $1(2)$.

Suryadinata, Leo (2007). The Decline of the Hegemonic Party System in Indonesia: Golkar After The Fall of Soeharto. Contemporary Southeast Asia: A Journal of International and Strategic Affairs 29(2), 333-358.

The City Mayors Foundation (2014) The Top 10 Mayors of World Mayor 2014. Retrieved from http://www.worldmayor.com/index. html

Transparency International (2004) Global Corruption Report 2004 [online]. England. Pluto Press. Retrieved from https://www.transparency.org/what wedo/publication/global_corruption _report_2004_political_corruption

Transparency International Indonesia (2013) Partai Politik, Terkorup Keempat di Indonesia. Retrieved from http:/ / www.ti.or.id/index.php/prior ity/2013/09/14/partai-politikterkorup-keempat-di-indonesia>

UNDP (1999) Decentralisation: A Sampling of Definitions. Retrieved from http://web.undp.org/evaluation/doc uments/decentralization_working_re port.PDF
Utami, I. S. (2018). Desentralisasi, Korupsi, Dan Tambal Sulam Pemerintahan Daerah Di Indonesia. Jurnal Pendidikan Kewarganegaraan, 5(1), 35-46.

Wirakusuma, K. Yudha (2014, 22 July) Perjalanan Panjang Jokowi ke Pintu Gerbang Istana. Metrotvnews. Retrieved from http:/ / pemilu.metrotvnews.com/rea d/2014/07/22/269305/perjalananpanjang-jokowi-ke-pintu-gerbangistana

Yuda A.R., Hanta (2010) Korupsi dan Industrialisasi Pilkada. Indonesia Corruption Watch. Retrieved http:/ / www.antikorupsi.org/id/cont ent/korupsi-dan-industrialisasipilkada 